\title{
Factors Influencing the Vaccination Programme for Newcastle Disease in Bangladesh: Disease Outbreaks, Haemagglutination-Inhibition Titres and Production under Field Conditions
}

\author{
M Rayhan Faruque $^{1 *}$, Jens P Christensen², Magne Bisgaard ${ }^{2}$, Bibek Chandra Roy ${ }^{3}$ and Paritosh Kumar Biawas ${ }^{1}$ \\ ${ }^{1}$ Chittagong Veterinary \& Animal Sciences University, Khulshi, Chittagong 4202, Bangladesh, ${ }^{2}$ Department of Pathobiology, Bülowsvej 17, University \\ of Copenhagen, Stigbøjlen 4, 1870 Frederiksberg C, Denmark, ${ }^{3}$ Department of Livestock Services (DLS), Livestock Research Institute (LRI), \\ Mohakhali, Dhaka 1212, Bangladesh
}

[Received 27 March 2007; Accepted 08 December 2007]

\begin{abstract}
The study was undertaken to examine the immune response of birds following the present Newcastle disease (ND) vaccination programme by haemagglutination-inhibition (HI) test ( $\beta$-procedure) from three study regions. This study also investigated factors possibly influencing the success of the vaccination programme. Though, those three farms had followed the different vaccination schedules, but using the same ND vaccines. Haemagglutination-inhibition (HI) titres at day-old were lower in Central Poultry Farm, Mirpur than Government Poultry Farms Jamalganj, Joypurhat and Bogra. Birds of these three farms did not persist challenge at day-old, because minimum $\mathrm{HI}$ titre for challenge was $\mathbf{2}^{4}$. But after introduction of ND vaccines, the HI titres showed the protective level $\left(>2^{4}\right)$. The $\mathrm{HI}$ titres were lower in Mirpur after introduction of ND vaccines than Joypurhat and Bogra. The $\mathrm{EID}_{50}$ of ND vaccines were determined before introduction to test the potency of vaccines. The embryo infective dose fifty $\left(\mathrm{EID}_{50}\right)$ of BCRDV (ND-F strain) was $10^{7.67}$ and the $\mathrm{EID}_{50}$ RDV (ND-' $M$ ' strain) was $10^{7.46}$ EID $_{50}$. It was done in the specific pathogen free (SPF) embryonating chicken eggs of 9-11 days of incubation. The bird mortality (\%) at three different farms was different from week 1 to week 30. The body weight gain of birds at 3 different farms was different. It was also related to hen day egg production percentage. The body weight of birds of the 3 farms was different from week 2 to week 30 . The intraocular vaccination of chicks with BCRDV (ND-F strain) at day 5 or day-old followed by vaccination with RDV (ND-M strain) by intramuscular route 8 weeks after primary vaccination and also before laying revaccination with RDV (ND-M strain) by intramuscular route would be a safe and efficient vaccination schedule.
\end{abstract}

Keywords: Newcastle disease (ND) virus, Vaccine, Haemagglutination-inhibition (HI) test, Embryo infective dose fifty $\left(\mathrm{EID}_{50}\right)$

\section{Introduction}

Newcastle disease (ND), popularly known as Ranikhet disease, sometimes Chunahaga in villages at Bangladesh, is recognized as one of the most important problems and most serious economic threat to the poultry production in Bangladesh. The disease is acute contagious which is characterized by sudden onset and rapid spread within the flock resulting high morbidity and mortality. ND is included in List A of the Office International des Epizooties ${ }^{1}$. Vaccination as a means of protecting birds against ND is routinely practiced in Bangladesh. Therefore, the types of vaccine, efficacy of the vaccine and vaccination schedule is very important when considering the protection of birds against ND. The types of vaccine and vaccination schedule adopted is influenced by a variety of factors such as antigenicity of vaccine virus, virulence of field virus, routes of vaccine administration and age of birds to be vaccinated ${ }^{2-3}$.
The current programme of ND vaccination in Bangladesh as followed by the Department of Livestock Services (DLS) includes administration of a live lentogenic vaccine of Asplin (F) strain by intra-ocular (i/o) instillation to chicks at day 3 and booster dose at day 28 followed by a live mesogenic vaccine of Mukteswar (M) strain by intramuscular ( $\mathrm{i} / \mathrm{m})$ injection to growing and adult birds usually, twice a year. But as the $\mathrm{M}$ strain is more invasive and pathogenic one, occasional report of post-vaccination outbreaks following the use of live $\mathrm{M}$ strain vaccine due to uncertainty or lack of records of primary vaccination with lentogenic strains could not be ignored ${ }^{2-3}$. Such vaccines and vaccination programmes have been found inadequate to protect chickens against ND in village conditions ${ }^{4}$. Therefore, this study was undertaken to evaluate the level of antibody production against Newcastle disease using haemagglutination-inhibition (HI) test. 


\section{Materials and Methods}

Study area and population

This study was undertaken at three Government Poultry Farms of Department of Livestock Services (DLS) in Bangladesh under Participatory Livestock Development Project (PLDP) area to examine the immune response of birds following the present Newcastle disease (ND) vaccination programme. Three government poultry farms Central Poultry Farm, Mirpur, Dhaka; Government Poultry Farm, Jamalganj, Joypurhat; and Government Poultry Farm, Bogra were selected in which 3 flocks of 3 selected farms containing minimum 1,000 birds from day-old (DO) to 30 weeks of age. Central Poultry Farm, Mirpur contains 34 poultry flocks / sheds; Government Poultry Farm, Jamalganj, Joypurhat contains 9 flocks; and Government Poultry Farm, Bogra contains 10 flocks.

\section{Vaccines and vaccine virus strains}

The live virus vaccines of Baby Chick Ranikhet Disease Vaccine (BCRDV) (Asplin or F strain) and Ranikhet Disease Vaccine (RDV) (Mukteswar or M strain) of Newcastle disease virus (NDV) from Livestock Research Institute (LRI), Department of Livestock Services (DLS), Mohakhali, Dhaka, were used in this study. In the label of BCRDV vial, it was $10^{8.00} \mathrm{EID}_{50}$ /bird, and in case of RDV it was $10^{7.00} \mathrm{EID}_{50}$ /bird. These vaccines were prepared by chicken embryo propagation following standard method of vaccine production of $\mathrm{FAO}^{2-3}$.

Embryo infective dose fifty $\left(\right.$ EID $\left._{50}\right)$ of ND vaccines $\mathrm{EID}_{50}$ of ND vaccines was measured at SPF embryonated chicken egg.

\section{Mortality records}

During the study period, weekly mortality was recorded in all three flocks of three selected farms. The record was taken from day-old to 30 weeks of age.

\section{Serum collection}

Sera were collected 11 times during the study period at day-old, 2, $4,6,8,11,15,20,23,26$ and 30 weeks of age from the three flocks of three selected farms. Blood was collected aseptically from brachial (wing) vein of the birds. Proper aseptic measures were taken during the time of blood collection. The collected blood samples were kept individually in sterile test tubes. After collection of the blood, the samples were kept in slanting position and left for 2-3 h at room temperature in order to separate the serum from the erythrocytes. Blood clots attached with the wall of the tubes were freed with the help of a sterile glass rod. The sera were then transferred to Eppendorf tubes and marked with the name of farm, number and collection date, and they were kept at $-20^{\circ} \mathrm{C}$ until examination.

\section{Haemagglutination-inhibition (HI) test}

The presence and level of ND antibodies were measured by using the heamagglutination-inhibition (HI) test according to OIE. PBS
(0.025 ml) was dispensed into each well of a plastic V-bottomed microtitre plate. Serum $(0.025 \mathrm{ml})$ was placed into first well of plate. Two-fold dilutions of $0.025 \mathrm{ml}$ volumes of the serum were made across the plate. Then, 4 haemagglutinating unit (HAU) virus/antigen was added in $0.025 \mathrm{ml}$ to each well and leave for a minimum $30 \mathrm{~min}$ at room temperature (i.e., about $20^{\circ} \mathrm{C}$ ). Chicken RBC $(0.025 \mathrm{ml}$ of $1 \%)$ was added to each well and after gentle mixing RBC was allowed to settle for $40 \mathrm{~min}$ at room temperature. The HI titre is the highest dilution of the serum causing complete inhibition of 4 HAU of antigen.

\section{Body weight measurement}

All birds from day-old to 30 weeks of age were weighted by the use of balance.

\section{Hen day egg production percentage}

Hen day egg production percentage was recorded from all three selected flocks of the three different farms from $1^{\text {st }}$ laying up to 30 weeks of age.

\section{Results}

The three different farms under investigation had different vaccination schedules, which are summarized in Table 1, 2 and 3.

The haemagglutination-inhibition (HI) titres of three different farms at different age groups of birds are given below (Table 4). The HI titres from day-old were lower in Central Poultry Farm, Mirpur, Dhaka, than Government Poultry Farms Jamalganj, Joypurhat and Bogra. Birds from these three farms did not persist challenge at day-old, because minimum $\mathrm{HI}$ titre for challenge was $2^{4}$. From the result here it appears as if day 5 would be a reasonable day to vaccinate. But after introduction of ND vaccines, the $\mathrm{HI}$ titres showed the protective level $\left(>2^{4}\right)$. The HI titres were lower in Mirpur after introduction of ND vaccines than Joypurhat and Bogra. The $\mathrm{EID}_{50}$ of ND vaccines were determined before introduction to test the potency of vaccines. It was done in the specific pathogen free (SPF) embryonating chicken eggs of 9-11 days of incubation. The EID $_{50}$ of BCRDV (ND-F strain) was $10^{7.67}$ and the $\mathrm{EID}_{50}$ RDV (ND-M strain) was $10^{7.46} \mathrm{EID}_{50}$.

The $\mathrm{EID}_{50}$ of ND vaccines were determined before introduction to test the potency of vaccines. It was done in the specific pathogen free (SPF) embryonating chicken eggs of 9-11 days of incubation. It was $10^{7.67} \mathrm{EID}_{50}$ /bird for BCRDV (Baby Chick Ranikhet Disease Vaccine) of ND-F strain, and laboratory result by Livestock Research Institute (LRI), Mohakhali, Department of Livestock Services (DLS) was $10^{8.00} \mathrm{EID}_{50}$ /bird. It was $10^{7.46} \mathrm{EID}_{50}$ / bird for RDV (Ranikhet Disease Vaccine) of ND-M strain, and laboratory result by Livestock Research Institute (LRI), Mohakhali, DLS was $10^{7.00} \mathrm{EID}_{50}$ /bird.

The bird mortality (\%) is shown in Table 5. The bird mortality (\%) at the three different farms was different from week one to week eighteen. The bird mortality at Mirpur was higher at week one than Joypurhat and Bogra. Mortality was highest (16\%) at Mirpur 
Faruque et al.

Table 1. Vaccination schedule for Central Poultry Farm, Mirpur, Dhaka

\begin{tabular}{llll}
\hline Age of birds & Name of vaccine & Route of inoculation & Dose/bird \\
\hline Day-old & $\begin{array}{c}\text { Bursaplex (Gumboro intermediate } \\
\text { plus strain) (Ag-Ab complex) }\end{array}$ & Intramuscular & $0.2 \mathrm{ml}$ \\
Day 6 & Newcastle live (F strain) & Intraocular & 2 drops \\
Day 21 & Newcastle live (F strain) & Intraocular & 2 drops \\
Day 30 & Fowl pox live & Wing web & 1 time with bi-forking needle \\
Day 60 & ND live (M strain) & Intramuscular & $1 \mathrm{ml}$ \\
Week 18 & ND live (M strain) & Intramuscular & $1 \mathrm{ml}$ \\
Week 21 & Gumboro killed & Intramuscular / Subcutaneous & $1 \mathrm{ml}$ \\
\hline
\end{tabular}

Table 2. Vaccination schedule for Government Poultry Farm, Jamalganj, Joypurhat

\begin{tabular}{llll}
\hline Age of birds & Name of vaccine & Route of inoculation & Dose/bird \\
\hline Day 3 & Newcastle live (F strain) & Intraocular & 2 drops \\
Day 12 & Gumboro live (D78 or TAD & Intraocular & 1 drop \\
& Gumboro Vac forte) & Intraocular & 1 drop \\
Day 21 & Gumboro live (D78 or TAD & & $1 \mathrm{ml}$ \\
Day 60 & Gumboro Vac forte) & Intramuscular & $0.3 \mathrm{ml}$ \\
Week 18 & ND killed (M strain) & Intramuscular / Subcutaneous & \\
\hline
\end{tabular}

Table 3. Vaccination schedule for Government Poultry Farm, Bogra

\begin{tabular}{llll}
\hline Age of birds & Name of vaccine & Route of inoculation & Dose/bird \\
\hline Day-old to Day 7 & Newcastle live (F strain) & Intraocular & 2 drops \\
Day 14 & Gumboro live (D78) & Intraocular & 1 drop \\
Day 19-21 & ND live (F strain)-booster dose & Intraocular & 2 drops \\
Day 22-24 & Gumboro live (D78) & Intraocular & 1 drop \\
Day 28-42 & Fowl pox live & Subcutaneous: wing-web & 1 time \\
Day 60 & ND live (M strain) & Intramuscular & $1 \mathrm{ml}$ \\
Day 75 & Fowl cholera & Subcutaneous & $1 \mathrm{ml}$ \\
Day 90 & Fowl cholera - booster dose & Subcutaneous & $1 \mathrm{ml}$ \\
Week 21-23 & ND live (M strain) & Intramuscular & $1 \mathrm{ml}$ \\
\hline
\end{tabular}

Table 4. Haemagglutination-inhibition (HI) titres (Mean \pm SD) of three different farms at different age groups of birds

\begin{tabular}{lccc}
\hline Age of birds & \multicolumn{3}{c}{ Haemagglutination-inhibition (HI) titer } \\
\cline { 2 - 4 } & $\begin{array}{c}\text { Central Poultry Farm } \\
\text { (Mirpur, Dhaka) }\end{array}$ & $\begin{array}{c}\text { Government Poultry Farm } \\
\text { (Jamalganj, Joypurhat) }\end{array}$ & $\begin{array}{c}\text { Government Poultry Farm } \\
\text { (Bogra) }\end{array}$ \\
\hline Day-old & $2^{2.40 \pm 1.45}$ & $2^{3.63 \pm 0.55}$ & $2^{3.63 \pm 0.55}$ \\
Week 2 & $2^{4.30 \pm 1.2}$ & $2^{5.96 \pm 0.71}$ & $2^{5.70 \pm 0.79}$ \\
Week 4 & $2^{4.90 \pm 0.68}$ & $2^{6.46 \pm 0.62}$ & $2^{7.56 \pm 0.5}$ \\
Week 6 & $2^{7.86 \pm 0.68}$ & $2^{5.83 \pm 0.74}$ & $2^{5.33 \pm 1.22}$ \\
Week 8 & $2^{4.86 \pm 0.68}$ & $2^{5.06 \pm 0.73}$ & $2^{5.53 \pm 0.74}$ \\
Week 11 & $2^{6.10 \pm 0.71}$ & $2^{6.46 \pm 0.62}$ & $2^{6.50 \pm 0.52}$ \\
Week 15 & $2^{7.30 \pm 0.7}$ & $2^{7.06 \pm 0.82}$ & $2^{6.70 \pm 0.95}$ \\
Week 20 & $2^{7.70 \pm 0.44}$ & $2^{7.46 \pm 0.57}$ & $2^{7.20 \pm 0.71}$ \\
Week 23 & $2^{8.00 \pm 0.88}$ & $2^{8.00 \pm 0.37}$ & $2^{8.03 \pm 0.61}$ \\
Week 26 & $2^{8.27} \pm 0.58$ & $2^{8.40 \pm 0.62}$ & $2^{8.00 \pm 0.78}$ \\
Week 30 & $2^{7.10 \pm 0.84}$ & $2^{7.90 \pm 0.66}$ & $2^{7.80 \pm 0.73}$ \\
\hline
\end{tabular}


at week one due to management factors like overcrowding. But at week two, mortality was lower at Mirpur (3\%) and higher at weeks 3 and 4 ( $8 \%$ for both weeks) than Joypurhat and Bogra. Mortality at Joypurhat continued up to week five which was $1 \%$, and at Mirpur up to week 12 (1\%), and at Bogra up to week 18 (0.5\%).

Table 5. Bird mortality (\%) at three different farms

\begin{tabular}{lccc}
\hline Age & \multicolumn{3}{c}{ Bird mortality (\%) } \\
\cline { 2 - 4 } & $\begin{array}{c}\text { Central } \\
\text { Poultry Farm } \\
\text { (Mirpur, Dhaka) }\end{array}$ & $\begin{array}{c}\text { Government } \\
\text { Poultry Farm } \\
\text { (Jamalganj, } \\
\text { Joypurhat) }\end{array}$ & $\begin{array}{c}\text { Government } \\
\text { Poultry Farm } \\
\text { (Bogra) }\end{array}$ \\
\hline Week 1 & 16 & 8 & 8 \\
Week 2 & 3 & 4 & 3 \\
Week 3 & 8 & 6 & 2 \\
Week 4 & 8 & 3 & 1 \\
Week 5-10 & $1-1$ & $0-1$ & $1-2$ \\
Week 11-15 & $0-1$ & 0 & $1.5-2$ \\
Week 16-20 & 0 & 0 & $0-1.5$ \\
Week 21-25 & 0 & 0 & 0 \\
Week 26-30 & 0 & 0 & 0 \\
\hline
\end{tabular}

The body weight of birds of the 3 farms was different from week two to week-thirty (Table 6). The birds at Mirpur were gaining slowly from week one to week thirty than Joypurhat and Bogra. The birds at Joypurhat were gaining well from week one to week thirty. The birds at Bogra were gaining slowly from week one to week two, and then well up to week three, and then again gaining slowly from week four to week thirty.

Table 6. Body weight of birds ( $g$ ) at three different farms

\begin{tabular}{lccc}
\hline Age & \multicolumn{3}{c}{ Body weight (g) of birds } \\
\cline { 2 - 4 } & $\begin{array}{c}\text { Central } \\
\text { Poultry Farm } \\
\text { (Mirpur, Dhaka) }\end{array}$ & $\begin{array}{c}\text { Government } \\
\text { Poultry Farm } \\
\text { (Jamalganj, } \\
\text { Joypurhat) }\end{array}$ & $\begin{array}{c}\text { Government } \\
\text { Poultry Farm } \\
\text { (Bogra) }\end{array}$ \\
\hline Day-old & 26 & 24 & 27 \\
Week 1 & 36 & 47 & 38 \\
Week 2 & 78 & 77 & 56 \\
Week 3-5 & $158-269$ & $123-270$ & $129-207$ \\
Week 6-10 & $333-527$ & $367-575$ & $312-556$ \\
Week 11-15 & $588-777$ & $604-805$ & $591-686$ \\
Week 16-20 & $831-887$ & $837-1,022$ & $714-912$ \\
Week 21-25 & $914-1,156$ & $1,188-1,275$ & $1,009-1,206$ \\
Week 26-30 & $1,223-1,470$ & $1,302-1,453$ & $1,258-1,429$ \\
\hline
\end{tabular}

The hen day egg production percentage was higher in Mirpur than in Joypurhat and Bogra (Table 7). The intraocular vaccination of chicks with BCRDV (ND-F strain) at day 5 or day-old followed by vaccination with RDV (ND-M strain) by intramuscular route 8 weeks after primary vaccination and also before laying revaccination with RDV (ND-M strain) by intramuscular route would be a safe and efficient vaccination schedule.

Table 7. Hen day egg production percentage at three different farms

Day of

laying

\begin{tabular}{ccc} 
& Egg production (\%) & \\
\hline Central & Government & Government \\
Poultry Farm & Poultry Farm & Poultry Farm \\
(Mirpur, Dhaka) & (Jamalganj, & (Bogra) \\
& Joypurhat) & \\
\hline 1 (Week 26) & 1 & 16
\end{tabular}

Day $1^{*} \quad 1$ (Week 26) 16

Day 2

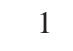

Day 3

Day 4

Day 5-8

Day 9

Day 10

Day 11

Day 12-14

Day 15

Day 16

Day 17

Day 18

Day 19-22

Day 23

Day 24

Day 25

Day 26-29

Day 30

Day 31

Day 32

Day 33-37

Day 38

Day 39

Day 40-44

Day 45

Day 46

Day 47-52

Day 53

Day 54-58

Day 60

Day 61-66

Day 67

Day 68

${ }^{*} 1^{\text {st }}$ laying.

\section{Discussion}

Results of this study cannot be compared easily because the three farms followed different vaccination schedules. Thus, the ideal vaccination schedule cannot easily be given. The level of maternal antibody, the type of vaccines, etc. will affect the outcome of the vaccination programme. Day-old chicks do not respond well to vaccination with high levels of maternal antibody present at the farms. Therefore, secondary vaccination is required. The HI titres of $2^{4}$ are level of protection ${ }^{1,5-6}$. 
The $\mathrm{EID}_{50}$ of BCRDV (ND-F strain) was $10^{7.67}$ and RDV (ND-M strain) was $10^{7.46} \mathrm{EID}_{50}$ and is similar to that of Faruque et al. ${ }^{7}$. But it does not similar to that of Allan et al. ${ }^{8}$. The reduced level could be due to transport facilities, problems in maintaining the cool chain, etc. However, the results a close to what is promised by the manufacturer.

The bird mortality (\%) at the three different farms was different from week one to week eighteen. The bird mortality at Mirpur is higher at week one than Joypurhat and Bogra. Mortality was highest (16\%) at Mirpur at week one probably due to overcrowding which caused quite a lot of problems. But at week two, mortality was lower at Mirpur (3\%) and higher at weeks 3 and 4 ( $8 \%$ for both weeks) than Joypurhat and Bogra. Mortality at Joypurhat continued up to week five which was $1 \%$, and at Mirpur up to week 12 (1\%), and at Bogra up to week 18 (0.5\%).

The body weight of birds of the three farms was different from week 1 to week 30 . The body weight of birds at Mirpur was gaining slowly from week 1 to week 30 than Joypurhat and Bogra. The birds at Joypurhat were gaining well from week 1 to week 30 . The birds at Bogra were gaining slowly from week 1 to week 2, and then well up to week 3 , and then again gaining slowly from week 4 to week 30 . The hen day egg production percentage was higher in Mirpur than in Joypurhat and Bogra.

In conclusion, it can be assumed that the intraocular vaccination of chicks with BCRDV (ND-F strain) at day 5 or day-old followed by vaccination with RDV (ND-M strain) by intramuscular route 8 weeks after primary vaccination and also before laying revaccination with RDV (ND-M strain) by intramuscular route would be a safe and efficient vaccination schedule.

\section{Acknowledgement}

We thank to the Danish Institutional Development Agency (DANIDA) through the Network for Smallholder Poultry Development in Denmark and Participatory Livestock Development Project (PLDP) in Bangladesh for financial support by a grant.

\section{References}

1. OIE. 1996. Newcastle disease. In Manual of Standards for Diagnostic Tests and Vaccines, $3^{\text {rd }}$ edn, pp 161-169. Office International des Epizooties (OIE), Paris.

2. Allan WH, Lancaster JE \& Tooth B. 1978. Newcastle Disease Vaccines, Their Production and Use, Chapter 3: Selection of the vaccine seed strain, pp 10-18. Food and Agricultural Organization of United Nations, Rome.

3. Allan WH, Lancaster JE \& Tooth B. 1978. Newcastle Disease Vaccines, Their Production and Use, Chapter 11: Vaccination programmes, pp 93-102. Food and Agricultural Organization of United Nations, Rome.

4. Chowdhury TIMFR, Sarker AJ, Amin MM \& Hossain WIMA. 1982. Studies on Newcastle disease in Bangladesh. A Research Report, Department of Micribiology and Hygiene, Bangladesh Agricultural University, Mymensingh, Bangladesh.

5. Allan WH \& Gough RE. 1976. Revista. Vet Sci. 20: 101-103.

6. Ibrahim AL, Lai MC \& Aini I. 1983. Spray vaccination with an improved F Newcastle disease vaccine. A comparison of efficacy with the $\mathrm{B}_{1}$ and LaSota vaccines. Br Vet J. 139(3): 213-219.

7. Faruque MR, Rahman ANMA \& Sarker AJ. 1999. Evaluation of the level of antibody production in chickens against Newcastle disease using haemagglutination-inhibition test. Bangladesh J Microbiol. 16(1): 35-42.

8. Allan WH, Lancaster JE \& Tooth B. 1973. Newcastle Disease Vaccines, Their Production and Use, Chapter 10: Programmes of Vaccination, pp 62-68. Food and Agricultural Organization of United Nations, Rome. 